\title{
Landscape Perception of the Bohemian Paradise
}

\author{
Martin Bušek, Martina Pásková, Josef Zelenka \\ e-mail: Martin.Busek@ronalgroup.com / martina.paskova@uhk.cz / josef.zelenka@uhk.cz
}

Department of Recreology and Tourism, Faculty of Informatics and Management, University of Hradec

Králové, Hradec Králové, Czech Republic

Bušek, M., Pásková, M., \& Zelenka, J. (2016). Landscape Perception of the Bohemian Paradise. Czech Journal of Tourism, 5(2), 111-133. DOI: 10.1515/cjot-2016-0007

\begin{abstract}
Comprehensive understanding of the destination perception by its visitors represents one of the key prerequisites of professional destination management on its both strategic and tactical level. This study continues in previous research focused on the analysis of the perception of different landscape types of the Czech Republic, zooming this time on the perception of the landscape of the Bohemian Paradise destination. The emphasis is put on the understanding of manifestations of genius loci and the exogenous factors in the landscape perception. The participant's observation of visitors' behaviour, evaluation of their spontaneous discussions and comments, structured interviews and introspection supplemented by recordings of exogenous factors represented methods used to get an insight into the perception of landscape and genius loci manifestation in the selected research localities. The qualitative research strategy in the form of pilot research led to the confirmation of suitability of applied methods and to the formulation of the preliminary hypotheses of the future quantitative research. The findings of this pilot research indicate the correctness of the assumption of the exogenous factors (weather, daytimes and seasons of the year) influence on the landscape perception as well as the manifestation of the genius loci perceived by the majority of visitors.
\end{abstract}

\section{Keywords}

Landscape perception, genius loci, exogenous factors, Bohemian Paradise, destination management

JEL classification: $L 83$ 


\section{Introduction}

Besides at least partially quantifiable destination characteristics such as tourism prerequisites and relative value of tourism potential, the constant attention of academics and destination management practitioners is dedicated to the destination perception by visitors as well as by other tourism stakeholders. Research of the destination perception is motivated not only by the efforts to understand its nature and roots in human cognition, but also by its potential use in the destination management and destination marketing practice.

The research presented in this article builds on the previous research of the landscape perception (Zelenka et al., 2008a), which was conducted in selected localities of seven regions of the Czech Republic. These regions represent various landscape types, including the urbanized landscape, ornamental landscape defined by UNESCO (2015, p. 72) „as landscape designed and created intentionally by man, semi-urbanized landscape and protected areas (quasi natural areas)". This research was carried out in the years of 2005-2007 close to the Prague periphery (urbanized landscape), Lednice-Valtice Cultural Landscape (ornamental landscape), in Central Bohemia Uplands and the Bohemian Paradise (semi-urbanized landscapes), Křivoklátsko (semi-urbanized with many quasi-natural areas), and in the Giant Mountains and Bohemian Forest (protected areas), see Figure 1. This research used sets of photographs for the examination and analysis of the perception of the typical sceneries of the above-mentioned landscape types.

To verify the results of this research and to develop further the research methodology of the landscape perception, the new pilot research on this topic was conducted in the years of 2014 and 2015 (Bušek, 2015) in one of the most popular tourist destinations of the Czech Republic, the Bohemian Paradise (Figure 1, Figure 3). This research focused on the immediate landscape perception of the sites selected in the Bohemian Paradise area. The main methods included participant observation of visitors' behaviour, analysis of spontaneous discussions among visitors, structured interviews conducted with the key actors as well as an introspection method. In this research, the emphasis are put on the influence of the exogenous factors of the landscape perception as well as on the manifestation of the phenomenon of genius loci perceived by visitors.

\section{Theoretical basis}

The presented research is based on the theoretical concepts and methods of cognitive psychology (Thagard, 2005; Zelenka et al., 2008b; Sternberg, Sternberg, \& Mio, 2011), representation of human thinking through cognitive and mental maps (Tolman, 1948; Lynch, 1960; Walmsley \& Jenkins, 1992; Kitchin, 1994; Young, 1999; Montello, 2002; Imani \& Tabaeian, 2012; Al-ghamdi \& Al-Harigi, 2015) and psychogeography and/or geopsychology (Šípek, 2001; Coverley, 2006; Šípek \& Štyrský, 2007; Self \& Steadman, 2007; Šípek, Kacetl, \& Štyrský, 2012) applied in the field of the tourism studies. The research in cognitive psychology, psychogeography and geopsychology application in tourism studies frequently focuses on the relationship of both destination perception and destination 
Figure 1 Sites of the landscape perception research conducted during the years of 2005-2007 and in the years of 2014-2015 in the Bohemian Paradise

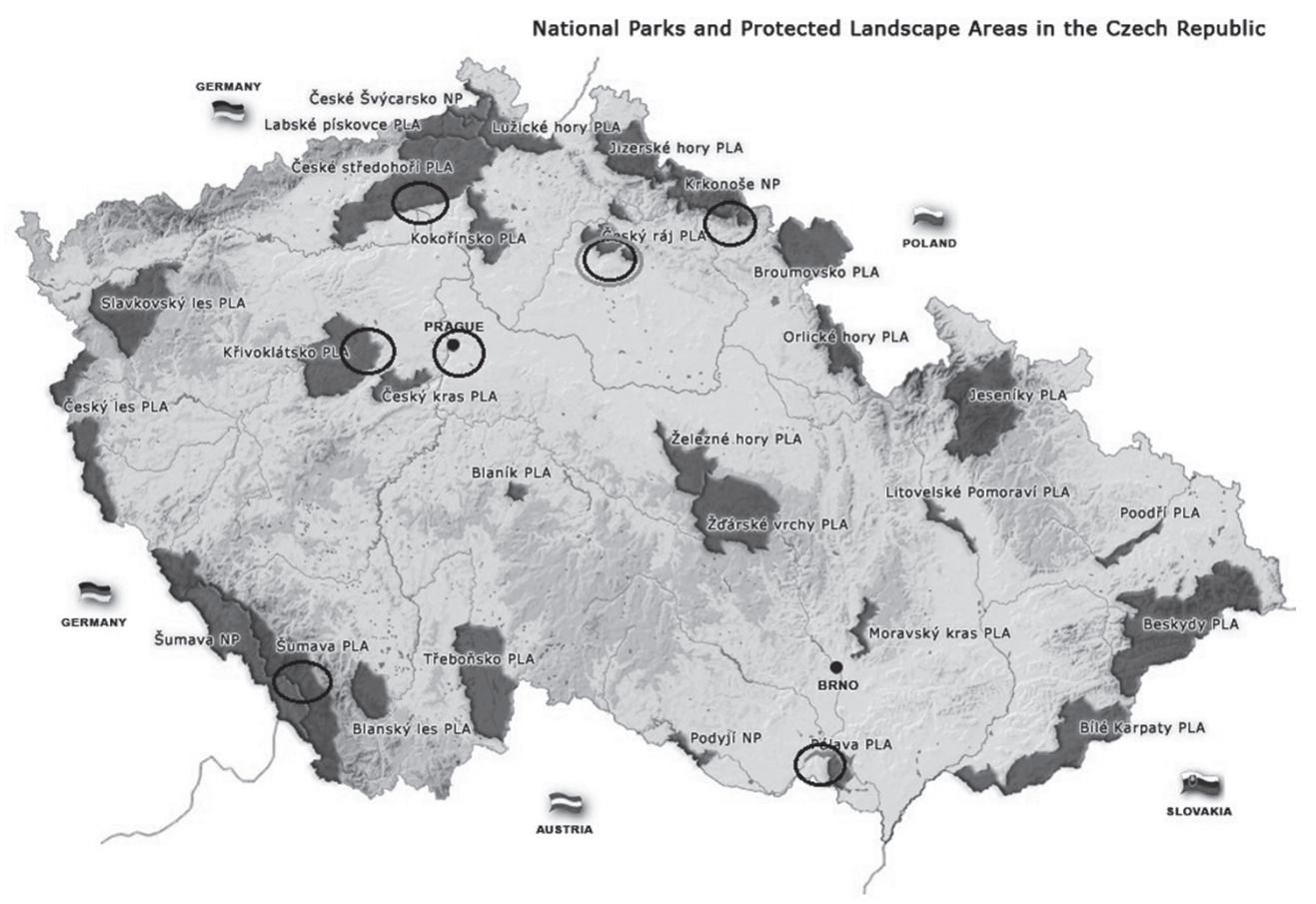

Note: Dark circles $=$ research conducted during the year of 2005-2007; Grey circle $=$ research conducted in the years of 2014-2015

Source: Adapted from NCA CR (2017)

cognition to its image (e.g., Echtner \& Ritchie 1991; Baloglu, 1999; Baloglu \& McCleary, 1999; Beerli \& Martín, 2004; Cohen, Prayag, \& Moital, 2014; Kock, Josiassen, \& Assaf, 2016), as well as to its cognitive and mental maps (Walmsley \& Jenkins, 1992; Young, 1999), and finally, to the visitor's motivation for repeated destination visits (e.g., Baloglu, 1999; Campo-Martínez, Garau-Vadell, \& Martínez-Ruiz, 2010; Rajesh, 2013). Some of these studies also focus on the influence of the destination authenticity on its perception by its visitors (Sedmak \& Mihalic, 2008; Buchmann, Moore, \& Fisher, 2010; Lu, Chi, \& Liu, 2015; Bryce et al., 2015), the relationship between the perception of changes in natural and socio-cultural prerequisites of the visited destination and its psychological carrying capacity (Jurado, Damian, \& Fernández-Morales, 2013; Salerno et al., 2013).

In the relevant studies, the attention is also paid to the influence of various exogenous factors on visitor's perception of destination (Ulrich, 1983; Zelenka et al., 2008a, 2008b; Svobodová, 2011; Rajesh, 2013). These factors include the agents, which are not 
related to destination itself such as the season of the year, weather, current state of the visitor's mind, and the presence of other close persons accompanying a visitor or the presence of other visitors. The specific phenomenon in the destination perception is the perception of the incidence and various individual specific manifestations of genius loci.

For a description of destinations perception, appropriate mental constructs are used. Besides the destination image (e.g., Baloglu, 1999; Beerli \& Martin, 2004; Rajesh, 2013), mainly the perceptual, cognitive (Walmsley \& Jenkins, 1992; Kitchin, 1994; Young, 1999; Montello, 2002; Özesmi \& Özesmi, 2004; Imani \& Tabaeian, 2012; Al-ghamdi \& AlHarigi, 2015) and mental maps (Zelenka et al., 2008b; Siwek, 2011; Hannes, Janssens, \& Wets, 2008) are used. The definition, mutual correlation and use of perceptual, cognitive and mental maps in cognitive research are already described by many authors (e.g., Zelenka et al., 2008b; Zelenka, Vybíral et al., 2013). The structure of perceptual, cognitive and mental maps and their changes are detected by the means of using appropriate techniques of structured and unstructured cognitive mapping (Zelenka \& Pásková, 2007; Zelenka et al., 2008b; Zelenka, Vybíral et al., 2013). The application of these maps enables the exploration of the phenomena such as potential visitor's motivation, visitor's behaviour (Hannes, Janssens, \& Wets, 2008), including his/her time-space paths (Lew \& McKercher, 2006), a change of destination perception due to the (repeated) visits of the destination ( $\mathrm{Li}$ et al., 2008), the most important destination components perceived by visitors (Baloglu, 1999), individual differences in the perceptions of the same place (Aragones \& Arredondo, 1985), visitors' way of orientation in the destination time-space, and effectiveness of the marketing communication implemented by the destination management organization.

Deep experience and unique perception of the destination is connected to the genius loci, which is often inaccurately referenced to the site ("the site has genius loci"). The genius loci cannot be simply described as an objective phenomenon occurring in the given landscape (e.g., Norberg-Schulz, 1991; Ouf, 2001; Jivén \& Larkham, 2003; Leus \& Herssens, 2015; Daldanise, 2016); it is much more the subjective experience of the specific time-space (see Figure 2). Based on the own research results, Zelenka et al. (2008a) and Zelenka (2009) describe the genius loci in the following way: the specific psychological condition, which, depending on many factors, is evoked in the individual by the given destination landscape. Strong subjective experience of the genius loci by an individual visitor could be crucial for motivating him/her to revisit the destination, for preferential visits of the similar places in the destinations, and for the transmission of this experience to other potential visitors of given destination by the means of the personal communication, or through the social media.

\section{Methodology}

To investigate the perception of the localities of the Bohemian Paradise destination, the qualitative research strategy was chosen with the key aims to understand how this perception is influenced by the exogenous factors, and what role the genius loci plays in it. 
Figure 2 Genius loci manifestation \& perception

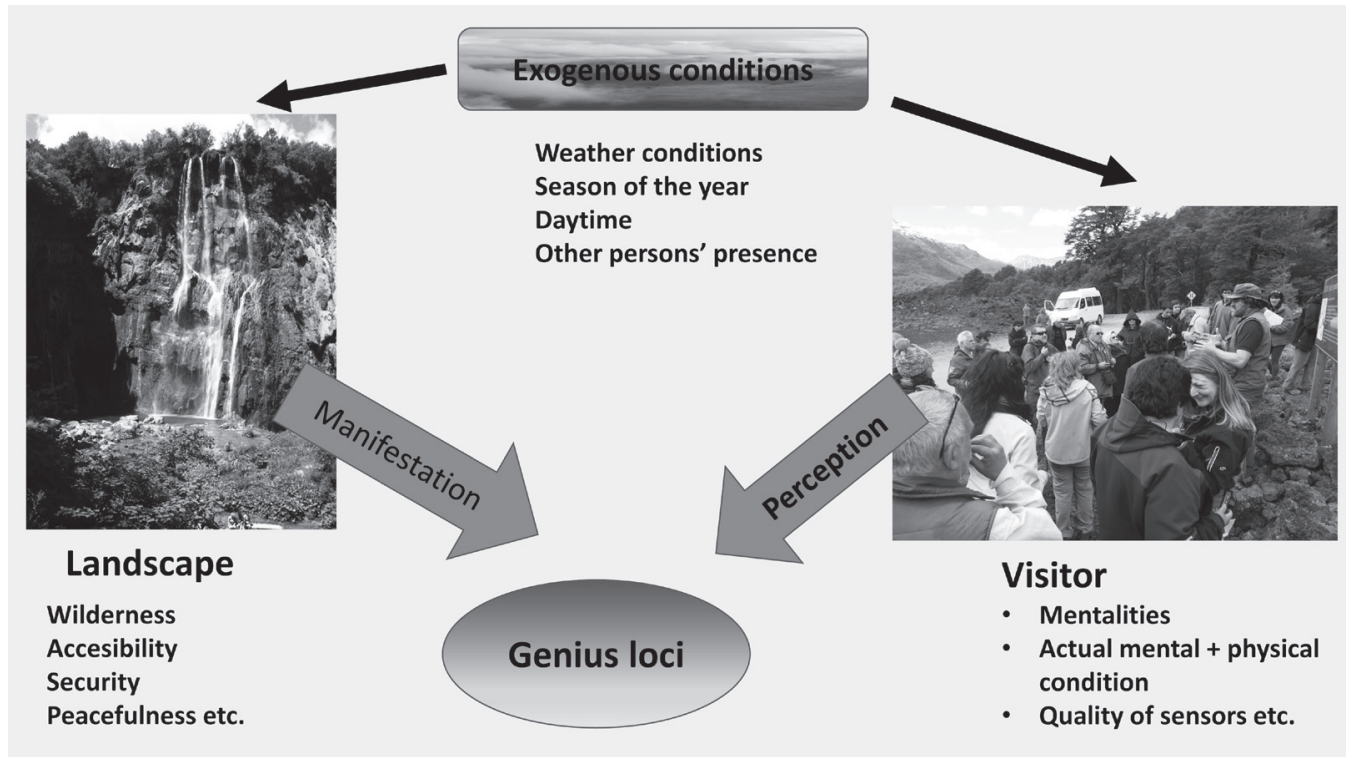

Source: Elaborated by Pásková (Photos: Zelenka, Pásková)

The following research questions were formulated:

- Do the visitors feel the genius loci in the selected localities of the Bohemian Paradise?

- Which differences in the landscape perception of the selected localities of the Bohemian Paradise destination can be identified among various visitors?

- Which differences in the genius loci perception can be identified between the selected localities of the Bohemian Paradise destination?

- How can the introspection method in the research on the visitors' landscape perception be used?

- Do the exogenous (non-destination) factors, i.e., atmospheric conditions, the daytime and season of the year, affect the genius loci perceived by the visitors on the given place?

Built on these research questions, the chosen research methodology included a suitable selection of research sites, research timing, i.e., different seasons of the year and day times as well as different atmospheric conditions. The exogenous factors of the research were constantly recorded. The qualitative research strategy (e.g., Walle, 1997; Riley \& Love, 2000; Wilson \& Hollinshead, 2015) was chosen to analyse the landscape perception on the selected sites, to verify the suitability of the chosen methodology and 
design the preliminary hypotheses for the potential future quantitative research in this field. The terrain research was based on participant's observation of the behaviour of visitors on the selected sites, including the recordings of their behaviour and the content of their talks. The evaluation of individual differences in visitor's perception were mainly based on monitoring the behaviour of the higher number of visitors. Spatial clusters of structured interviews conducted in the research localities brought also some indications and evidence values (see Table 1). The structured interviews were conducted in the form of open-ended questions and these interviews as well as the systematically observed behaviour of the interviewed individuals were evaluated in the context of researcher's introspection.

\section{Selection and characterization of the research sites}

The research was conducted on eight selected sites of the Bohemian Paradise destination (Figure 3). The Bohemian Paradise probably represents the oldest and most popular tourist destination; the oldest large size protected area and the only UNESCO Global Geopark in the Czech Republic (Pánek \& Hradecký, 2016). In this area, the typologically ${ }^{1}$ different localities were chosen for the qualitative research of the landscape perception. All these research sites represent well-known, physically accessible and frequently visited places. The research was conducted in different seasons of the year, different day times, as well as under different atmospheric conditions. The selected research sites (black circles in Figure 3) represent the most popular cultural and natural attractions of the Bohemian Paradise, where the genius loci perceived by visitors is highly probable.

Two of the research sites were located in the Prachovské Rocks - The Vyhlídka Míru Viewpoint (Figure 4) and the Zátiší Rocks (Figure 5). The Prachovské Rocks represent the largest area of the Bohemian Paradise, where the perception of genius loci could be expected. The sand stone rock cities create a variety of scenery and in combination with special sunlight, snow effects or coloured leaves can cause a variety of feelings, emotions and ideas.

The research also included the Trosky Castle ruins (Figure 6), which are considered a symbol of the Bohemian Paradise. The Trosky Castle ruins, built on the basalt hill, create the magical place, highly visible in the landscape. They attract the attention of visitors from afar. The castle offers a breath-taking view over the Bohemian Paradise landscape. The connection of the castle ruins, the volcano outcrops and the outlook over the landscape creates the ideal conditions for the genius loci to be perceived, defined by sense of romance, emotions for nature and admiration of the ancestors' footprints in the landscape.

From the ruins, castles and chateaux preserved in the landscape of Bohemian Paradise, the relatively small chateau Humprecht was also selected for the research (Figure 7). This hunting chateau is a construction of unusual shape, hidden among the trees

1) in the context of landscape typology 
Figure 3 The research sites marked on the map of the Bohemian Paradise destination

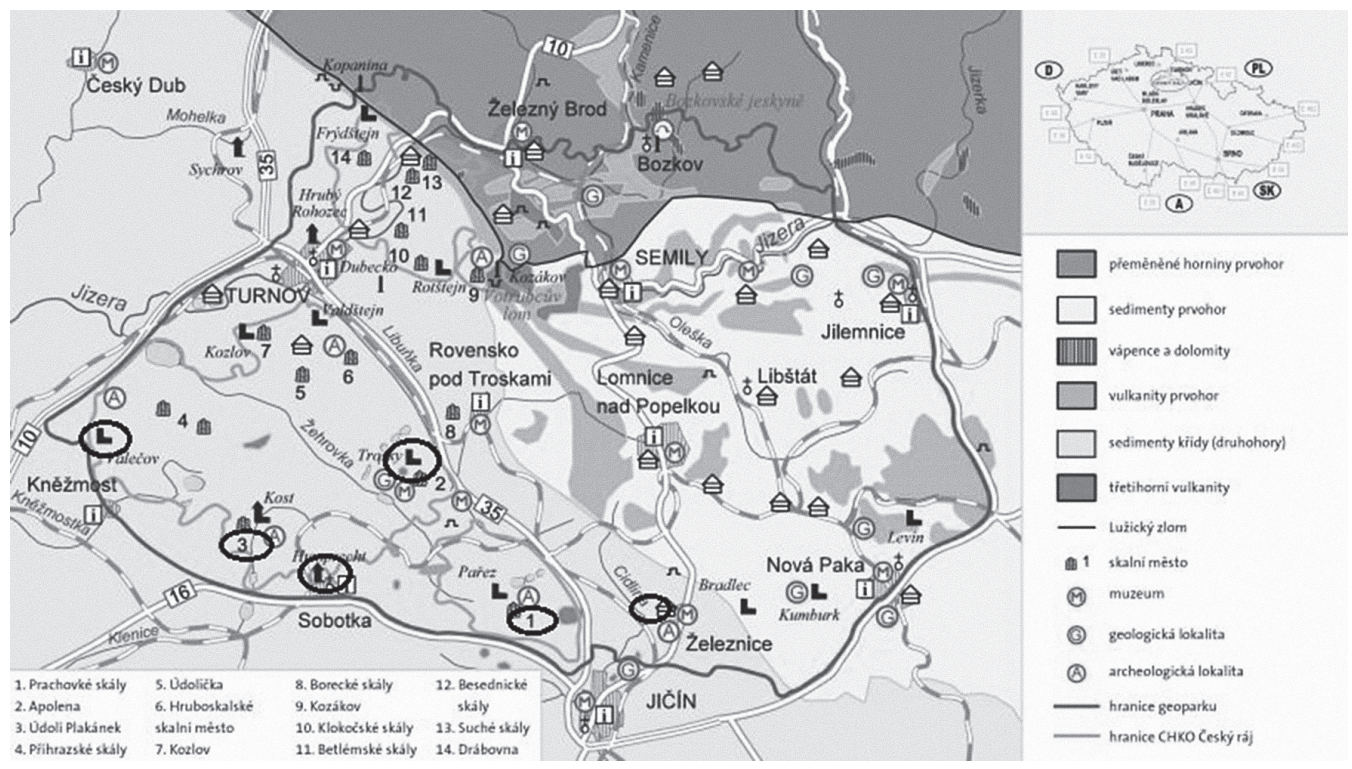

Source: Adapted from the Bohemian Paradise Association (2017)

Figure 4 The Prachovské Rocks - The Vyhlídka Míru Viewpoint in summer and winter seasons
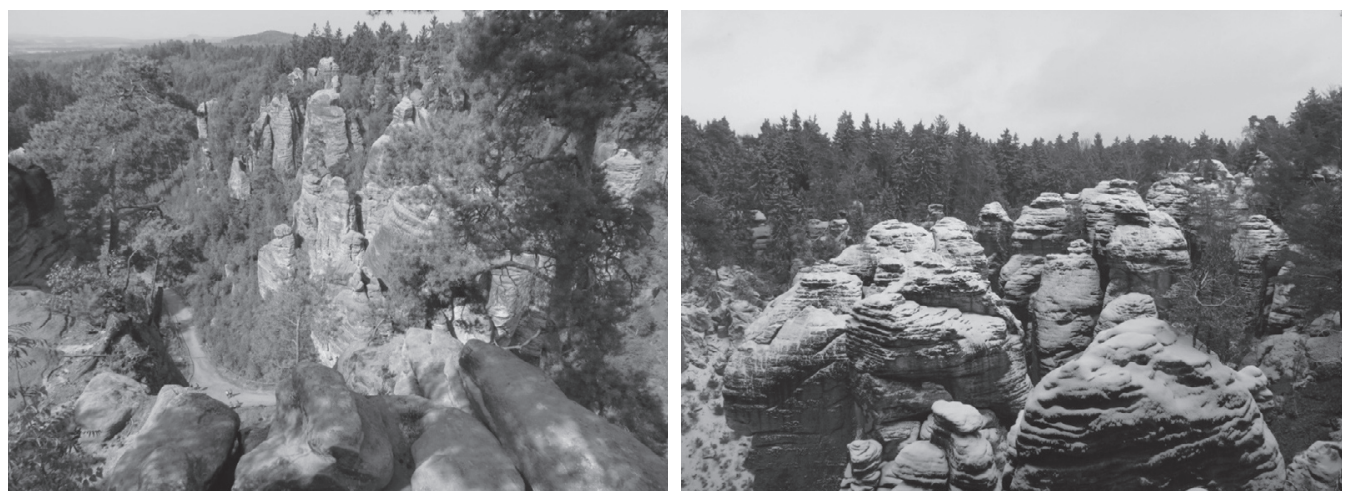

Source: Bušek (2015) 
Figure 5 The Prachovské Rocks - the Zátiší Rocks in summer and winter seasons
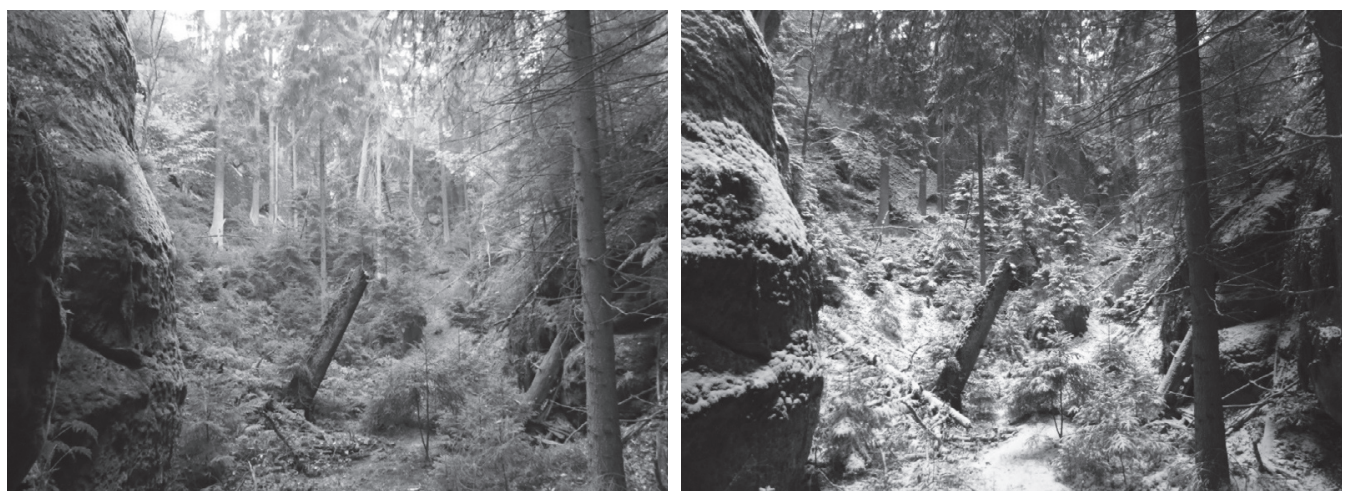

Source: Bušek (2015)

Figure 6 Trosky Castle ruins under different weather conditions
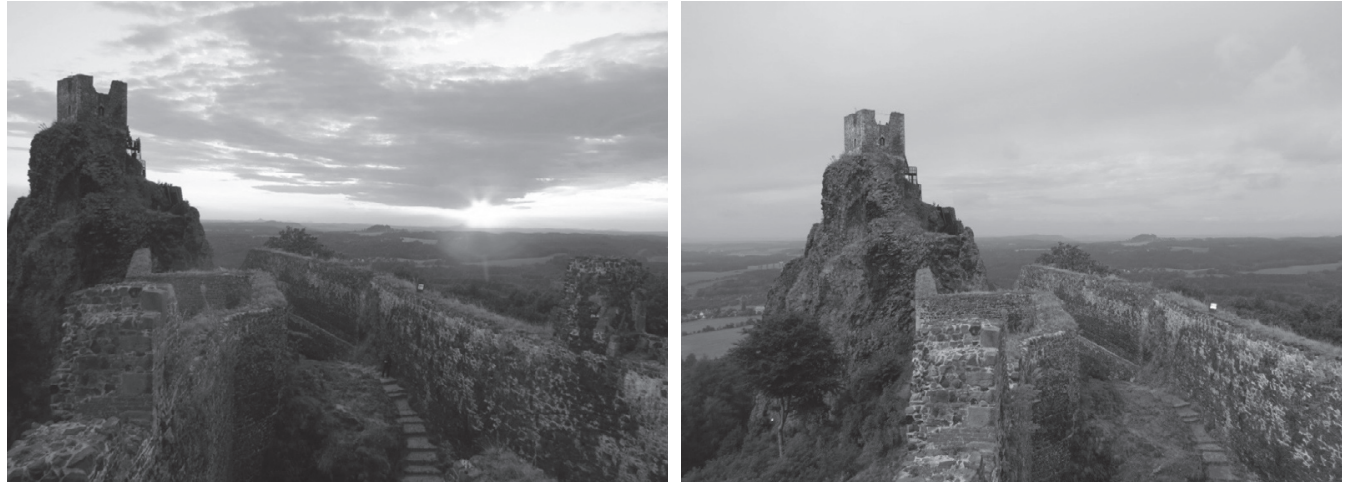

Source: Bušek (2015)

and bushes, which can awake an imagination in people as well as to evoke the ancient times and stories.

The research was conducted also in the romantic Plakánek Valley (Figure 8), combining rocks, trees, water and variability of the sunlight. These are good conditions for enjoying the atmosphere of the place, romance, admiration and uplifting feelings.

Among the cultural attractions of the Bohemian Paradise, the Valečov Castle ruins (Figure 9) and Rocks dwellings (Figure 10) in the neighbourhood (cultural and natural attractions) were included into the set of the research sites.

One of the many hills of the Bohemian Paradise, Zebín basalt hill (Figure 11), including the views of the surroundings was also selected as a suitable pilot research site 
Figure 7 Chateau Humprecht in summer and winter seasons and under different weather conditions
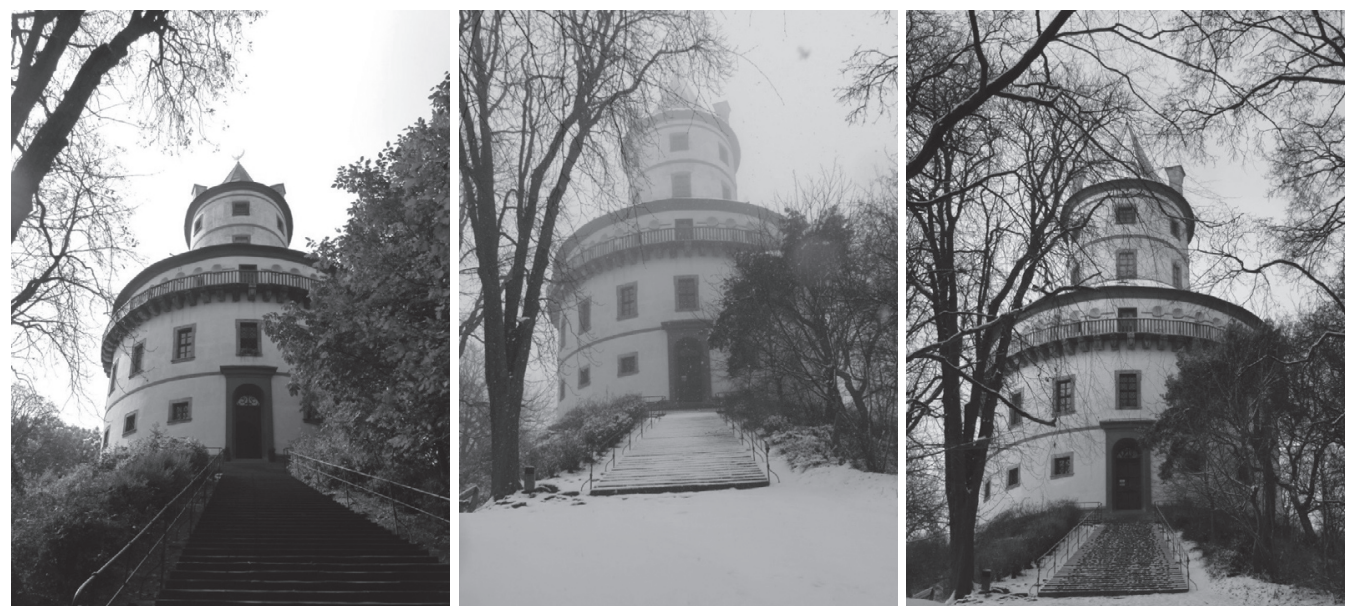

Source: Bušek (2015)

Figure 8 Plakánek Valley - different views
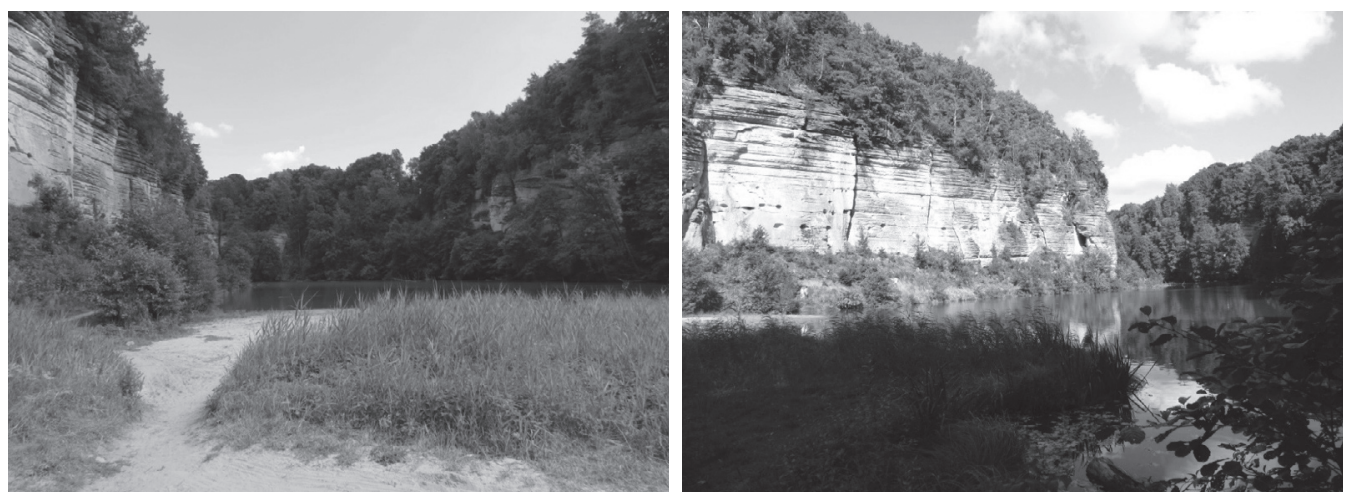

Source: Bušek (2015) 
Figure 9 Valečov Castle ruins in summer and winter seasons
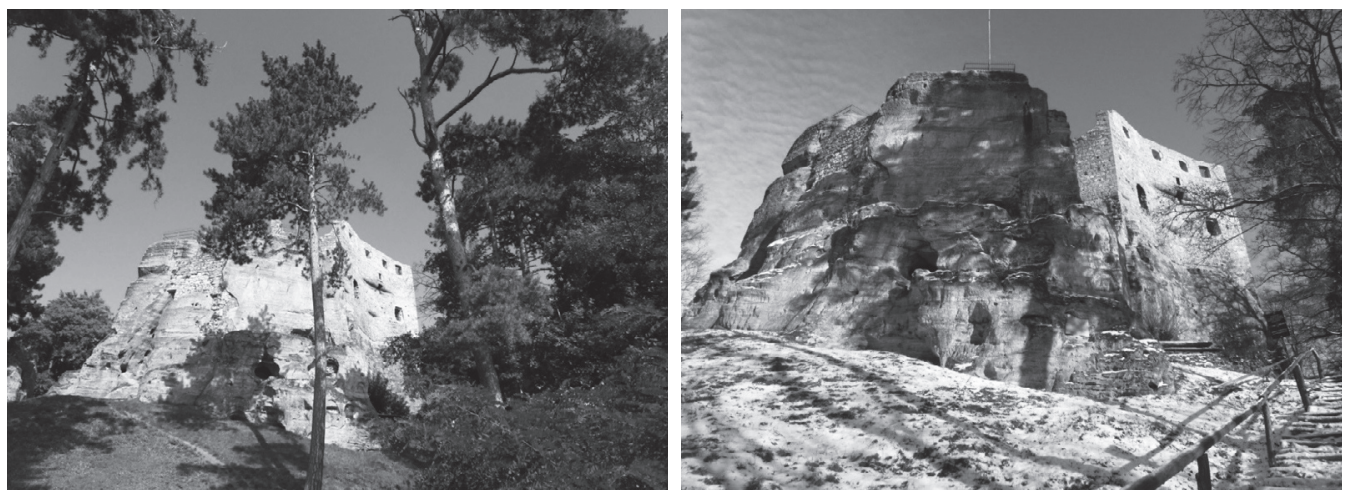

Source: Bušek (2015)

Figure 10 Valečov Rocks dwellings in summer and winter seasons
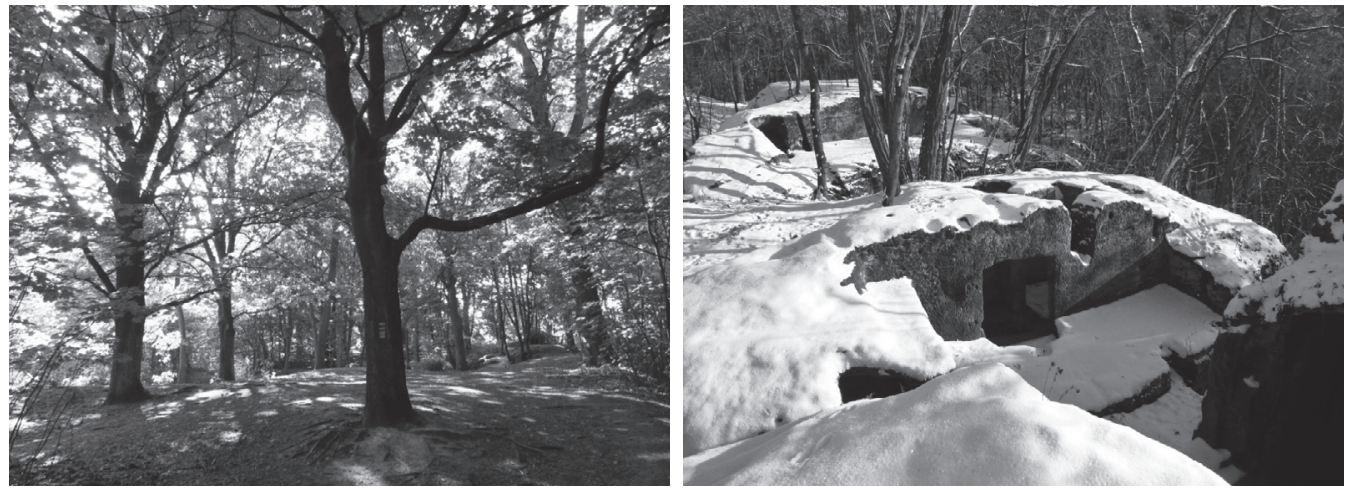

Source: Bušek (2015)

Figure 11 Zebín Hill under different weather conditions
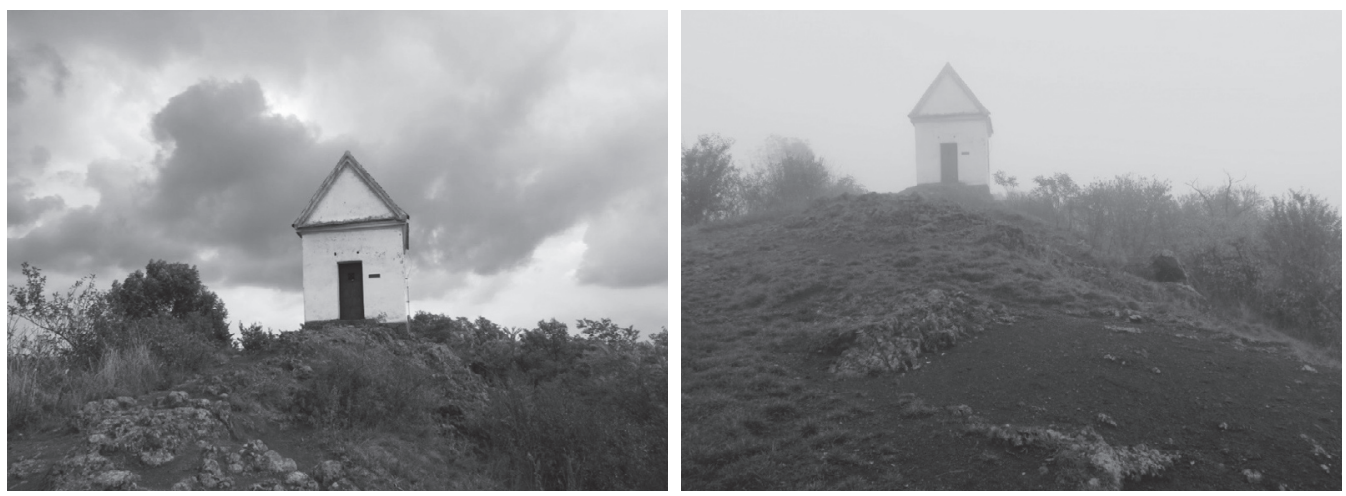

Source: Bušek (2015) 


\section{Methodology of observations and interviewing}

Prior to the future intended implementation of extensive research, the pilot quantitative research to evaluate the suitability of the proposed methodology (research steps, content of questioning, role of the exogenous factors and inclusion of introspection) was conducted. The pilot research on the selected research sites consisted of four basic stages:

1. Before the interviews, the visitors could experience the time for their undisturbed experience and enjoyment of the researched site.

2. With chosen individuals, pairs or small groups of people, the structured interviews with open questions were then conducted. These questions were related to the respondents' feelings and perceptions. Typical open questions were as follows: "Does this place provoke any feelings in your mind and/or body? Is there something at the place which makes it attractive to you?" The additional questions to support the statement of the respondent then were: "Does this place remind you of anything? Does this place raise any memories to you?".

3. Direct questioning was supplemented by participant's observation and listening to the pairs or to the small groups of persons. Through observations, comparisons and evaluations of the pilot research results, it was discovered that visitors were more communicative and more open when speaking with each other than with the interviewer.

4. As part of the research method, the researcher used the incorporate introspective expression of interviewer's perceptions of the site, and evaluation of his impression, produced by the interaction with the visitor.

\section{Results}

\section{Territorial scope of the pilot research}

The pilot research was conducted on all eight selected localities of the Bohemian Paradise during the years of 2014-2015 (Table 1). The research based on the participant's observation of visitors' behaviour and wiretapping (when possible) of their mutual discussions, involved 3,172 visitors. The structured interviews were conducted with 189 visitors. 
Table 1 Research sites and the key parameters of the pilot research

\begin{tabular}{|l|c|c|c|}
\hline Place & Period of research & $\begin{array}{c}\text { Number of visitors } \\
\text { - behaviour and } \\
\text { interviews analysis }\end{array}$ & $\begin{array}{c}\text { The total number } \\
\text { of intensive } \\
\text { interviews }\end{array}$ \\
\hline $\begin{array}{l}\text { Prachovské Rocks -Vyhlídka } \\
\text { Míru Viewpoint }\end{array}$ & $06.09 .2014-06.01 .2015$ & 594 & 19 \\
\hline Prachovské Rocks - Zátiší Rocks & $07.09 .2014-29.12 .2014$ & 54 & 4 \\
\hline Ruins of Trosky Castle & $23.07 .2014-27.01 .2015$ & 402 & 15 \\
\hline Chateau Humprecht & $06.06 .2014-27.01 .2015$ & 155 & 9 \\
\hline Plakánek Valley & $11.08 .2014-31.12 .2014$ & 254 & 15 \\
\hline Ruins of Valečov Castle & $12.08 .2014-08.02 .2015$ & 89 & 16 \\
\hline $\begin{array}{l}\text { Rock dwellings near } \\
\text { the ruins of Valečov Castle }\end{array}$ & $12.08 .2014-30.12 .2014$ & 34 & 3 \\
\hline Zebín Hill & $14.08 .2014-31.12 .2014$ & 8 & \\
\hline
\end{tabular}

Source: Bušek (2015)

\section{Perception of the genius loci perceived on the research sites}

As shown in the graph (Figure 12), most of the visitors on the selected research sites perceived the genius loci. On three of the surveyed sites, all the interviewed visitors perceived the genius loci. The same results were confirmed by the participant's observation of visitors' behaviour, evaluation of their mutual discussions, as well as the researcher's introspection. The presence of a large number of people on the site was the most important element disturbing the ability of the genius loci perception. Other disturbing factors were the extreme atmospheric conditions and man-made distractions such as the smoke, screams and the sound of firecrackers ${ }^{2}$.

\section{Other aspects of the landscape perception}

Feelings of the respondents connected to the perception of the landscape scenes were largely positive or neutral, see Figure 13. The results have shown that at any given timespace different respondents may have had both positive and negative feelings. A clear link between the negative emotions of visitors to the sites surveyed and atmospheric conditions, respectively associated with different seasons, has not been discovered. The negative feelings were in fact recorded under different atmospheric conditions during different seasons of the year.

The pilot research results indicate that the exogenous factors, i.e., atmospheric conditions, day times, and seasons of the year, do influence the landscape perception of the

2) Results regarding the disturbance produced by firecrackers is stemming from the research conducted on the day of the New Year's Eve. 
Figure 12 Genius Loci perception

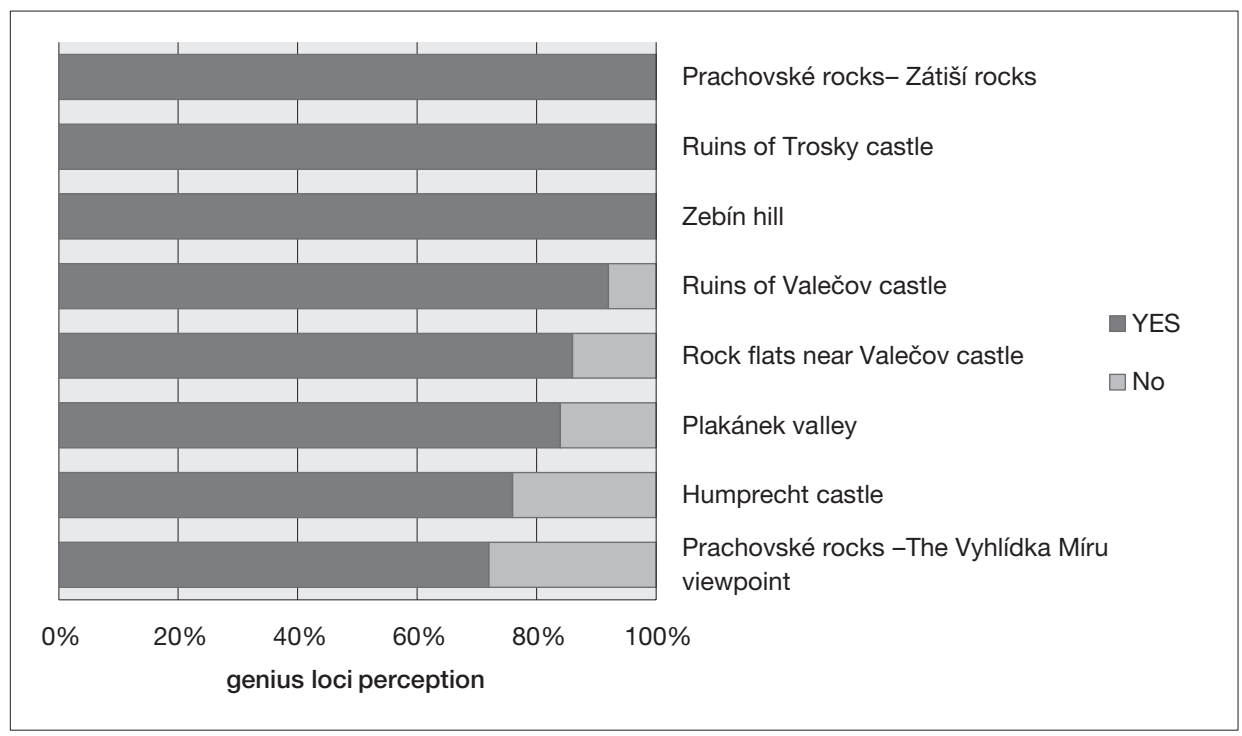

Source: Bušek (2015)

Figure 13 Emotional characteristics of the landscape perception

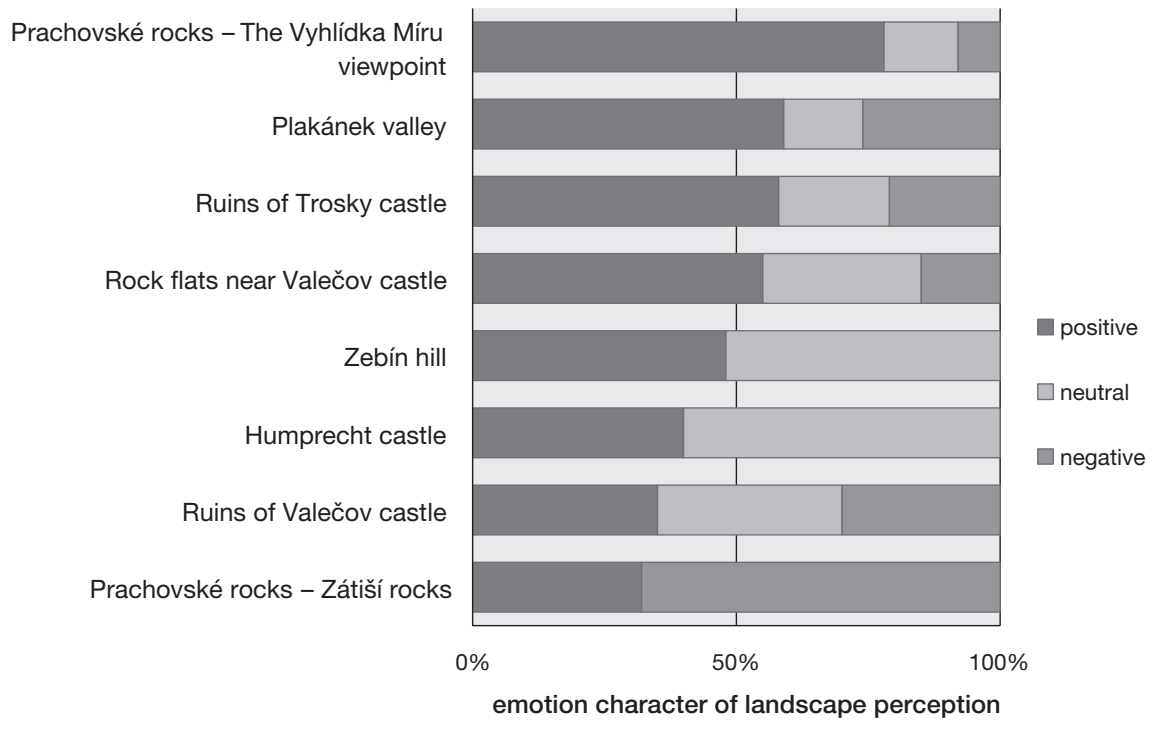

Source: Bušek (2015) 
Figure 14 Perceived effects of the exogenous factors

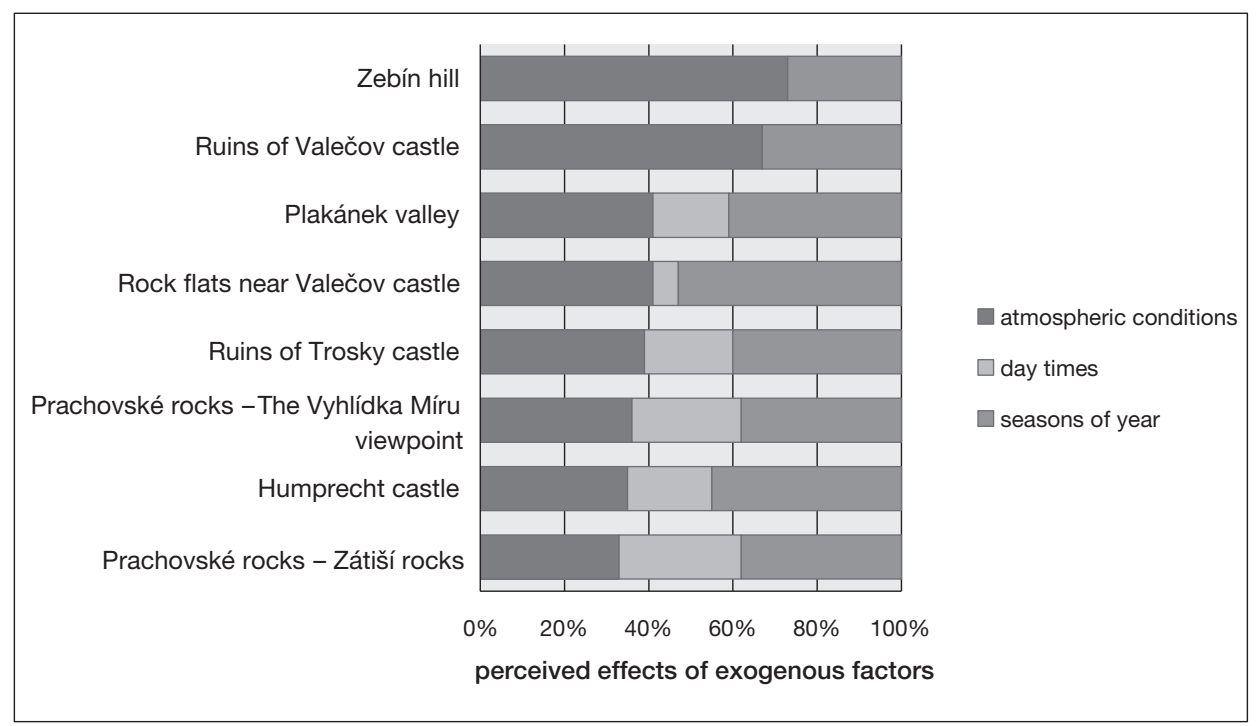

Source: Bušek (2015)

Figure 15 Perception recorded at the Prachovské Rocks -Vyhlídka Míru Viewpoint

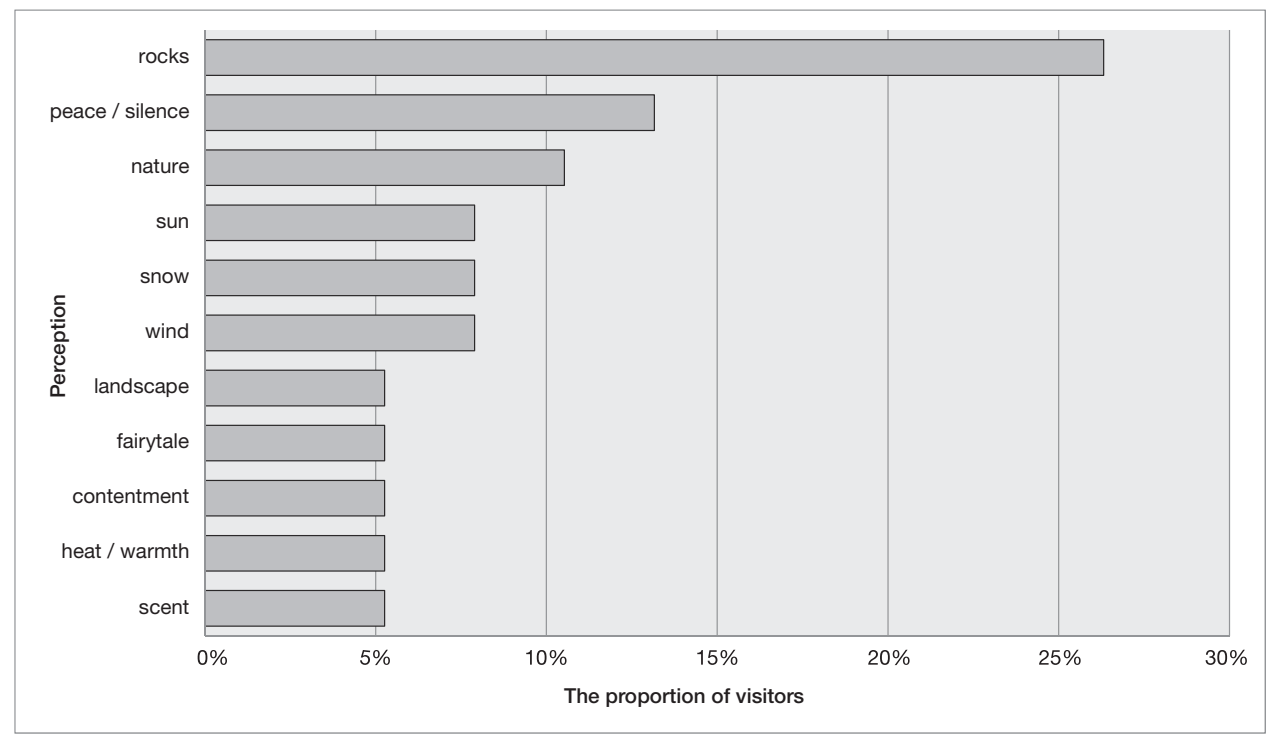

Source: Bušek (2015) 
Figure 16 Perception recorded at the Ruins of Trosky Castle

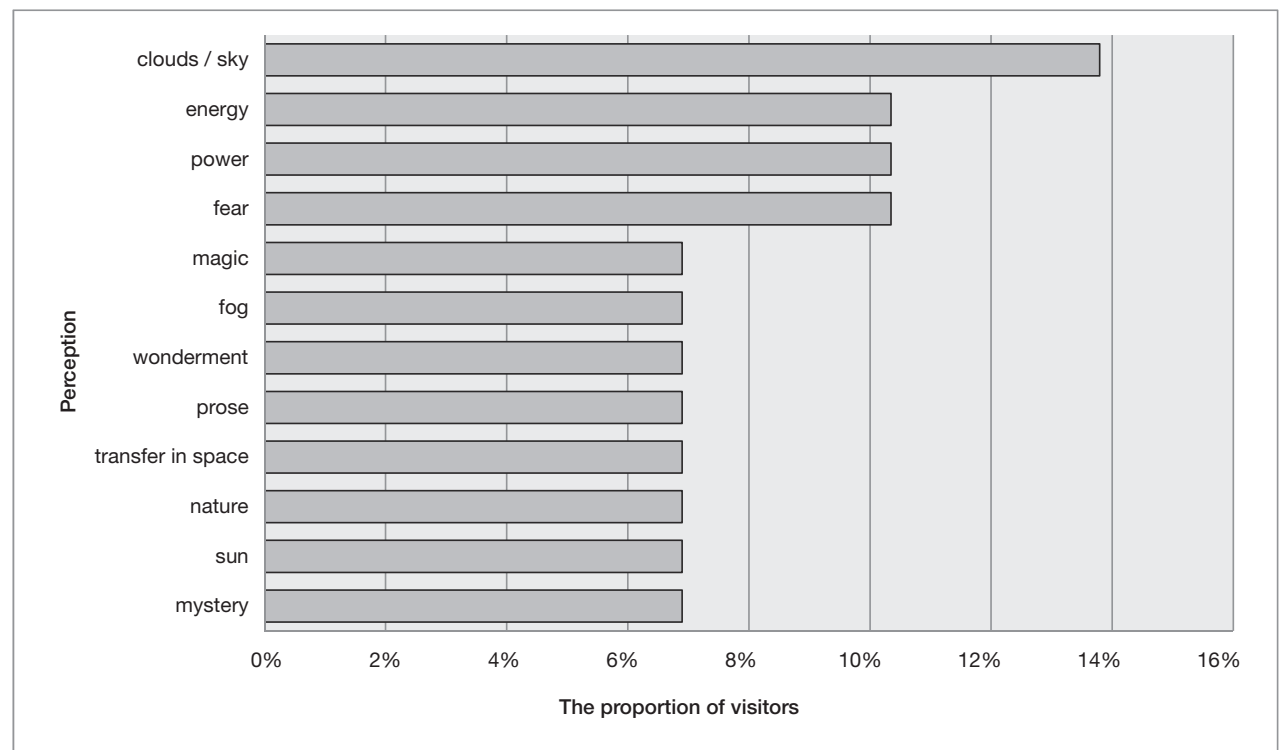

Source: Bušek (2015)

Figure 17 Perception recorded at Chateau Humprecht

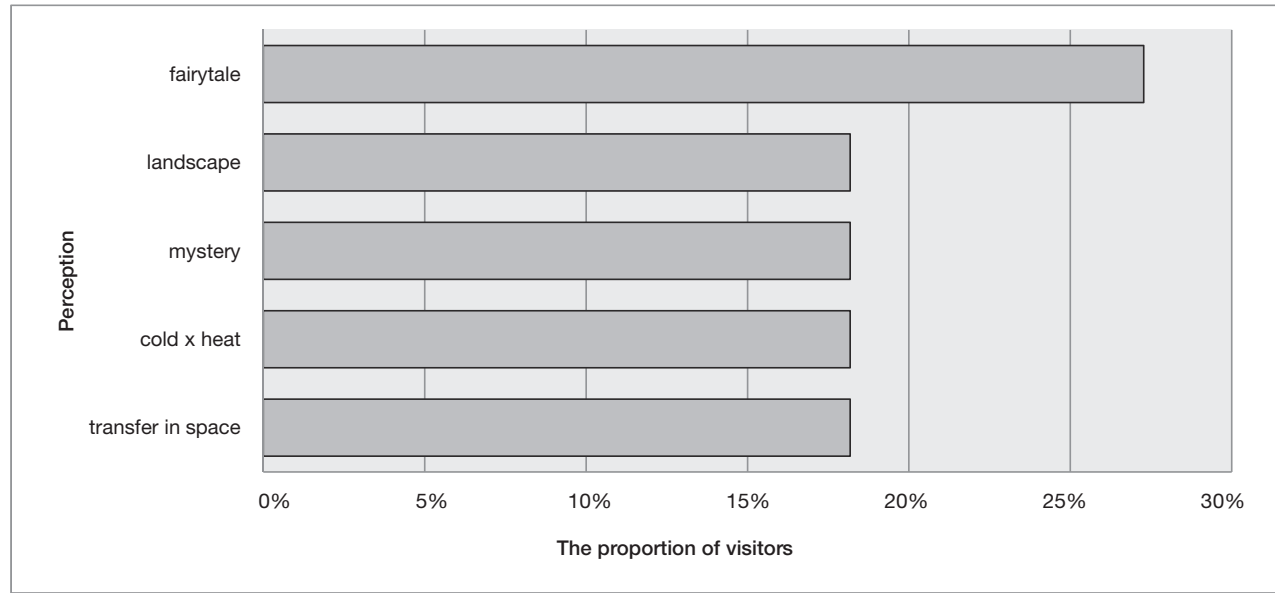

Source: Bušek (2015) 
Figure 18 Perception recorded in Plakánek Valley

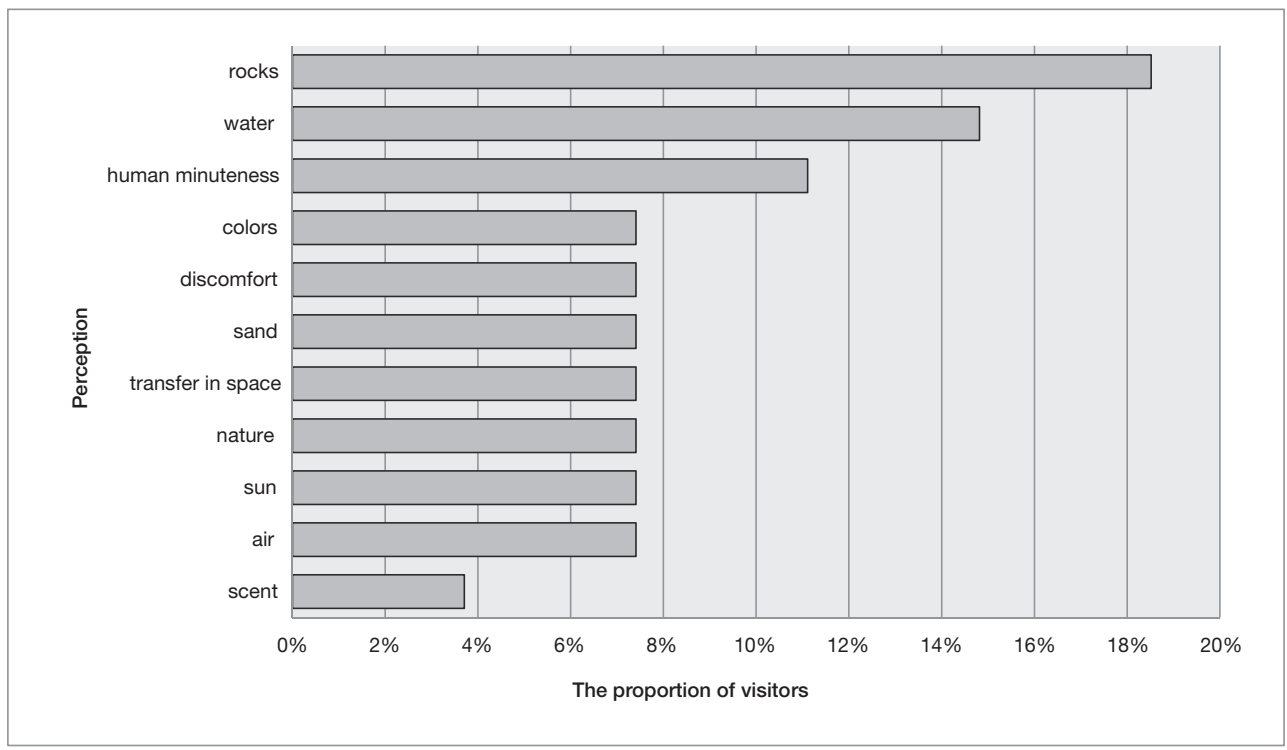

Source: Bušek (2015)

Figure 19 Perception recorded at the Ruins of Valečov Castle

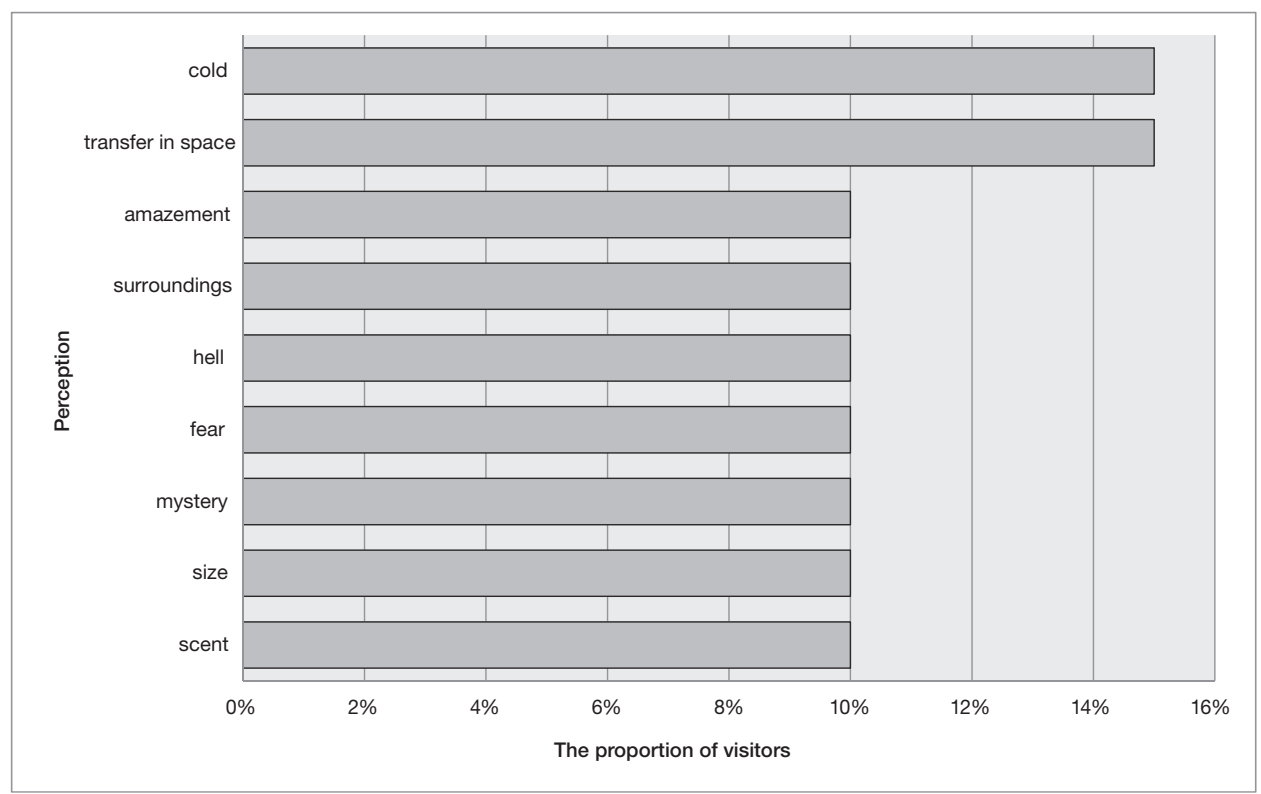

Source: Bušek (2015) 
Figure 20 Perception recorded at the Rock dwellings near the ruins of Valečov Castle

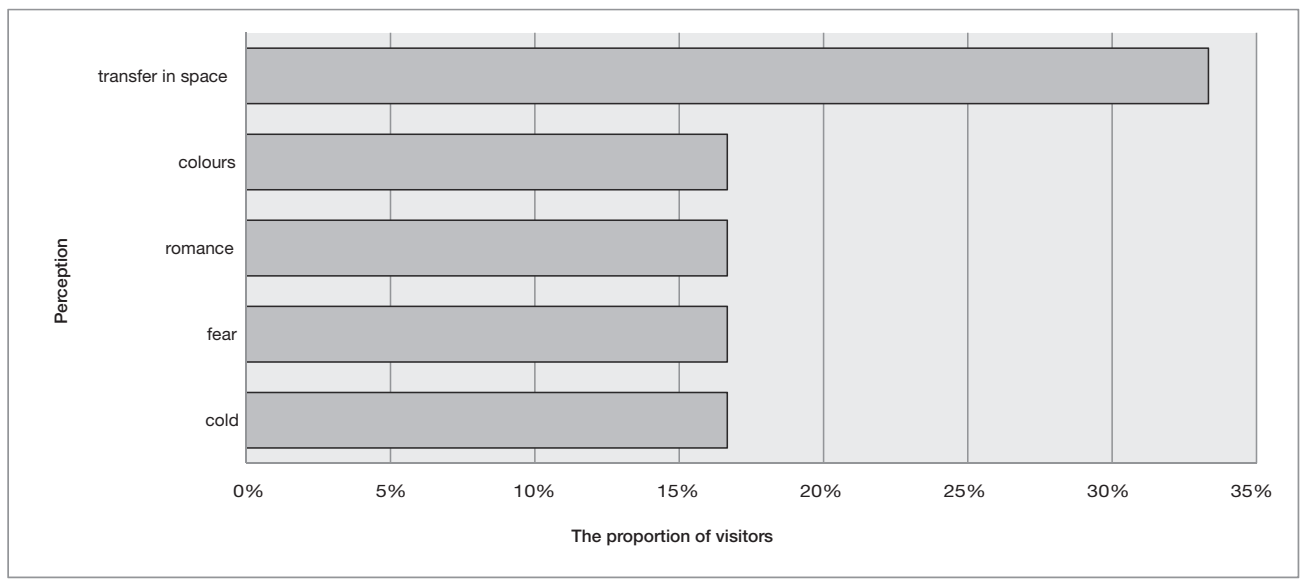

Source: Bušek (2015)

research localities as well as the manifestation of the genius loci perceived at these sites. Through the analysis of respondents' answers to the open questions and the evaluation of spontaneous expressions of visitors during their mutual talks, it was found out that their landscape perception was approximately equally influenced by both atmospheric conditions and seasons of the year. The effect of day times on the visitors' perception in most places (except Zebín Hill and the Prachovské Rocks - the Zátiší Rocks) has been less important (Figure 14). During the perception process, different combinations of these exogenous factors, manifested by various synergies of their influence, were typically employed.

The big amount of the expressions describing the visitors' feelings evoked by all the perceived researched sites, including the genius loci manifested by them, were recorded during this pilot research. The summary of these feelings on the research sites are illustrated bellow in Figure 15 - Figure 20. Because of a relatively small amount of data, two research sites (Zebín Hill and the Prachovské Rocks - the Zátiší Rocks) were not included in these figures.

- At the Prachovské Rocks (Vyhlídka Míru Viewpoint, see Figure 15), visitors perceived both material and immaterial natural phenomena, mainly rocks, sun, wind, snow and silence.

- On the contrary, at the Trosky Castle Ruins (see Figure 16) visitors perceived except the sun, sky, fog, and surrounding nature, also certain energy, magic, mystery, fear and power, which can be interpreted as a clear evidence of the genius loci perception.

- At Humprecht Chateau (see Figure 17), the most frequent feeling perceived by the visitors was a fairytale, followed by feelings of mystery, cold versus heat, transfer in time and landscape. 
- In the Plakánek Valley (see Figure 18), visitors mainly perceived (similarly as at the Prachovské Rocks) nature, rocks, water, sun or sand. Except these feelings, they also experienced human insignificance (in relation to the natural powers).

- At Valečov Castle Ruins (see Figure 19) and Valečov Rock Dwellings (see Figure 20), similar dominant feelings were recorded as cold, mystery, fear and the most frequent feeling was the perception of transfer in time. These research sites are very close to each other, but very different. The castle is located on the top of the rocks and it is opened from three sites to the surroundings. On the contrary, the rock dwellings are located in the forest. The presence of a certain type of energy is thus possible and it creates similar atmosphere of both research sites.

Based on the results of this pilot research, the preliminary hypotheses for the future extensive qualitative research were formulated in the following way:

1. The majority of the Bohemian Paradise visitors perceive the genius loci manifested by its landscapes.

2. The dispersion of emotional character of the landscape perceptions varies substantially between various landscape types of the Bohemian Paradise.

3. Other persons' presence, atmospheric conditions and the daytime significantly affect the genius loci perception of the Bohemian Paradise landscapes.

\section{Discussion}

The qualitative pilot research conducted in the Bohemian Paradise confirms the results of the previous research results implemented at FIM UHK (Zelenka et al., 2008a, $2008 \mathrm{~b}$ ). It indicates that the landscape perception (including the genius loci perception as the specific phenomenon manifested by these landscapes) is significantly influenced by other persons' presence, seasons of the year, weather conditions and partly, by the daytime $^{3}$. It is disputable if the situation when the visitor was not able to describe his/ her perception of the place including the genius manifested by this place, does mean that he/she did not really have any perception of this. The participant's observation as an additional method brought a very important value in this sense. In accordance with Zelenka et al. (2008a, 2008b), it was preliminary confirmed that the landscape perception (regarding both its intensity and quality) is to some extent individual. A new interesting finding was that the dispersion of individual perceptions varied substantially in different research localities.

3) The daytime scope of the research did not include the night time 
Table 2 Comparison of localization and number of sites, methodology and research results in $2005-2007$ and $2014-2015$

\begin{tabular}{|l|l|l|}
\hline $\begin{array}{l}\text { Aspect of } \\
\text { research }\end{array}$ & \multicolumn{1}{|c|}{ Research 2005-2007 } & \multicolumn{1}{|c|}{ Research 2014 - 2015 } \\
\hline Destination & $\begin{array}{l}\text { Prague surroundings, Lednice-Valtice } \\
\text { area, Central Bohemia Uplands, } \\
\text { Bohemian Paradise, Krivoklátsko, } \\
\text { Giant Mountains, Bohemian Forest }\end{array}$ & Bohemian Paradise \\
\hline $\begin{array}{l}\text { Type of } \\
\text { research }\end{array}$ & $\begin{array}{l}\text { Comparative research on landscape } \\
\text { perception on typologically different } \\
\text { sites }\end{array}$ & $\begin{array}{l}\text { In-depth research for given places } \\
\text { Focus - sites perception including } \\
\text { genius loci }\end{array}$ \\
\hline $\begin{array}{l}\text { Number of } \\
\text { research sites }\end{array}$ & $\begin{array}{l}\text { More than 600 research sites (nearly } \\
\text { 100 sites in each of 7 landscape } \\
\text { types) }\end{array}$ & $\begin{array}{l}\text { 8 research sites in Bohemian } \\
\text { Paradise }\end{array}$ \\
\hline $\begin{array}{l}\text { Methodology } \\
\text { of research }\end{array}$ & $\begin{array}{l}\text { Content analysis of the landscape } \\
\text { perception using 100 photographs } \\
\text { of sites for each landscape type, in- } \\
\text { depth content analyses of 15 sites in } \\
\text { each landscape type }\end{array}$ & $\begin{array}{l}\text { Participant's observation of visitors' } \\
\text { behavioural, evaluation of the } \\
\text { content of the spontaneous visitors' } \\
\text { interviews, structured interviews, } \\
\text { introspection }\end{array}$ \\
\hline Results & $\begin{array}{l}\text { New methodology } \\
\text { Comparison of perception of more } \\
\text { than 600 sites } \\
\text { Findings of important elements } \\
\text { perceived by the landscape visitors }\end{array}$ & $\begin{array}{l}\text { New methodology } \\
\text { The rate of appearance of the genius } \\
\text { loci } \\
\text { The emotional character of the } \\
\text { landscape perception } \\
\text { Influence of exogenous factors on } \\
\text { visitors' perception }\end{array}$ \\
\hline
\end{tabular}

Source: Zelenka et al. (2008a), Bušek (2015)

\section{Conclusion}

The Bohemian Paradise represents a unique area for its geological heritage (Pánek \& Hradecký, 2016), the way of coexistence between man and nature (rock dwellings, rock castles and chateaux using the maximum configuration of the terrain), as well as the way of developing local culture including the handcrafts based on geo-heritage (e.g., stonecutting, jewellery and other decorative arts made of Czech garnet, agate and other local precious stones). This special history, popularity and uniqueness of the Bohemian Paradise landscape create mutually interconnected set of conditions for the manifestation of the genius loci phenomenon which can be perceived by visitors.

The pilot research results indicate that the majority of the Bohemian Paradise visitors perceive the genius loci manifested by its landscape. Regarding the differences in the landscape perception of the selected localities of the Bohemian Paradise destination among various visitors, the indication is that all the visitors perceive some localities 
positively, while the other localities are perceived positively only by some. The dispersion of emotional character of those perceptions substantially varies between the selected sites. The differences were also indicated in genius loci perception on the selected localities of the Bohemian Paradise destination among various visitors. All the visitors perceived the genius loci on three research sites. However, on the other five localities there was a percentage of visitors who did not perceive it. The findings of this pilot research also indicate that the exogenous factors, mainly the atmospheric conditions and season of the year as well as the presence of other persons, significantly affect the genius loci perceived by the visitor of the Bohemian Paradise destination. These pilot research results indicate interesting differences in the genius loci perception between the selected localities of the Bohemian Paradise destination.

The pilot research also confirmed the suitability of the set research methodology, which could be used for the implementation of the future qualitative research of the landscape perception with an emphasis on the perceived effects of the genius loci phenomenon. The introspection proved to be a useful method for the research of the visitors' perception of landscape because it enabled the comparison of the visitors' perceptions with the perception of the experienced researcher. In addition, it involved a critical assessment of the exogenous factors effects.

Based on the results of this pilot research, the preliminary hypotheses for the abovementioned future extensive research were formulated. The results of such an extensive qualitative research, especially when it is implemented in the long-term systematic way, have potential to enhance not only the level of the understanding of the mental (emotional and cognitive) processes of the visitors, but above all, to improve the performance of the destination management, mainly in its marketing activities, visitor management and implementation of the corporate social responsibility.

\section{Acknowledgement}

The financial support of the Specific Research Project "Information and knowledge management and cognitive science in tourism" of FIM UHK is gratefully acknowledged. The authors would like to thank Paul Zejda for graphs processing and design.

\section{References}

Al-ghamdi, S. A., \& Al-Harigi, F. (2015). Rethinking Image of the City in the Information Age. Procedia Computer Science, 65, 734-743. DOI: 10.1016/j.procs.2015.09.018.

Aragones, J. I., \& Arredondo, J. M. (1985). Structure of urban cognitive maps. Journal of Environmental Psychology, 5(2), 197-212. DOI: 10.1016/S0272-4944(85)80017-7.

Baloglu, S. (1999). A Path Analytic Model of Visitation Intention Involving Information Sources, Socio-Psychological Motivations, and Destination Image. Journal of Travel and Tourism Marketing. 8(3), 81-90. DOI: 10.1300/J073v08n03_05 
Baloglu, S., \& McCleary, K. W. (1999). A model of destination image formation. Annals of Tourism Research, 26(4), 868-897. DOI: 10.1016/S0160-7383(99)00030-4.

Beerli, A., \& Martín, J. D. (2004). Factors Influencing Destination Image. Annals of Tourism Research, 31(3), 657-681. DOI: 10.1016/j.annals.2004.01.010.

Bohemian Paradise Association (2017). 22 stops in the Bohemian Paradise Geopark. Retrieved from http:/ / www.cesky-raj.info/dr-en/3132-22-stops-in-the-bohemian-paradise-geopark.html.

Bryce, D., Curran, R., O’Gorman, K., \& Taheri, B. (2015). Visitors' engagement and authenticity: Japanese heritage consumption. Tourism Management, 46, 571-581. DOI: 10.1016/j.tourman.2014.08.012.

Buchmann, A., Moore, K., \& Fisher, D. (2010). Experiencing Film Tourism: Authenticity \& Fellowship, Annals of Tourism Research, 37(1), 229-248, doi:dx.doi.org/10.1016/j.annals.2009.09.005.

Bušek, M. (2015). Genius loci v cestowním ruchu. Genius loci Českého ráje (Genius loci in Tourism. Genius loci in Bohemian Paradise). Bachelor theses. Hradec Králové, Czech Republic: University of Hradec Králové.

Campo-Martínez, S., Garau-Vadell, J. B., \& Martínez-Ruiz, M. P. (2010). Factors influencing repeat visits to a destination: The influence of group composition. Tourism Management, 31(6), 862-870. DOI: 10.1016/j.tourman.2009.08.013.

Cohen, S. A., Prayag, G., \& Moital, M. (2014). Consumer behaviour in tourism: Concepts, influences and opportunities. Current Issues in Tourism, 17(10), 872-909. DOI: $10.1080 / 13683500.2013 .850064$.

Coverley, M. (2006). Psychogeography. Pocket Essential Series. Harpenden, England: Oldcastle Books.

Daldanise, G. (2016). Innovative Strategies of Urban Heritage Management for Sustainable Local Development. Procedia - Social and Behavioral Sciences, 223, 101-107. DOI: 10.1016/j.sbspro.2016.05.318.

Echtner, C. M., \& Ritchie, I. R. B. (1991). The Meaning and Measurement of Destination Image. Journal of Tourism Studies, 2(2), 2-12.

Hannes, E., Janssens, D., \& Wets, G. (2008). Destination Choice in Daily Activity Travel: Mental Map's Repertoire. Transportation Research Record: Journal of the Transportation Research Board, 2054(), 20-27. DOI: 10.3141/2054-03.

Imani, F., \& Tabaeian, M. (2012). Recreating mental image with the aid of cognitive maps and its role in environmental perception. Procedia - Social and Behavioral Sciences, 32, 53-62. DOI: 10.1016/j.sbspro.2012.01.010.

Jivén, G., \& Larkham, P. J. (2003). Sense of Place, Authenticity and Character: A Commentary. Journal of Urban Design, 8(1), 67-81. DOI: 10.1080/1357480032000064773.

Jurado, E. N., Damian, I. M., \& Fernández-Morales, A. (2013). Carrying Capacity Model Applied in Coastal Destinations. Annals of Tourism Research, 43, 1-19. DOI: 10.1016/j.annals.2013.03.005.

Kitchin, R. M. (1994). Cognitive maps: What are they and why study them? Journal of Environmental Psychology, 14(1), 1-19. DOI: 10.1016/S0272-4944(05)80194-X.

Kock, F., Josiassen, A., \& Assaf, A. G. (2016). Advancing destination image: The destination content model. Annals of Tourism Research, 61, 28-44. DOI: 10.1016/j.annals.2016.07.003.

Leus, M., \& Herssens, J. (2015). The Soundscapes of Antwerp: A Study on the Acoustic Genius Loci. Energy Procedia, 78, 25-30. DOI: 10.1016/j.egypro.2015.11.109.

Lew, A., \& McKercher, B. (2006). Modeling Tourist Movements. A Local Destination Analysis. Annals of Tourism Research, 33(2), 403-423. DOI: 10.1016/j.annals.2005.12.002. 
Li, X., Cheng, C.-K., Kim, H., \& Petrick, J. F.(2008). A systematic comparison of first-time and repeat visitors via a two-phase online survey. Tourism Management, 29(2), 278-293. DOI: 10.1016/j. tourman.2007.03.010.

Lu, L., Chi, Ch. G., \& Liu, Y. (2015). Authenticity, involvement, and image: Evaluating tourist experiences at historic districts. Tourism Management, 50, 85-96. DOI: 10.1016/j.tourman.2015.01.026.

Lynch, K. (1960). The Image of the City. Cambridge, USA/London, England: The MIT Press.

Montello, D. R. (2002). Cognitive map-design research in the twentieth century: Theoretical and empirical approaches. Cartography and Geographic Information Science, 29(3), 283-304. DOI: $10.1559 / 152304002782008503$.

Nature Conservation Agency of the Czech Republic [NCA CR]. (2017). The map of National Parks and Protected Landscape Areas in the Czech Republic. Retrieved from http://www.cittadella.cz/ europarc/index.php?p=mapa_NP_CHKO_text\&site=zakladni_udaje_en.

Norberg-Schulz, C. (1991). Genius Loci: Towards a Phenomenology of Architecture. New York, USA: Rizzoli.

Ouf, A. M. S. (2001). Authenticity and the sense of place in urban design. Journal of Urban Design, 6(1), 73-86. DOI: 10.1080/13574800120032914.

Özesmi, U., \& Özesmi, S. L. (2004). Ecological models based on people's knowledge: a multi-step fuzzy cognitive mapping approach. Ecological Modelling, 176(1-2), 43-64. DOI: 10.1016/j.ecolmodel.2003.10.027.

Pánek, T., \& Hradecký, J. (Eds.) (2016). Landscapes and Landforms of the Czech Republic. Springer International Publishing. DOI: 10.1007/978-3-319-27537-6.

Rajesh, R. (2013). Impact of Tourist Perceptions, Destination Image and Tourist Satisfaction on Destination Loyalty: A Conceptual Model. PASOS. Revista de Turismo y Patrimonio Cultural, 11(3), 67-78.

Riley, R. W., \& Love, L. L. (2000). The state of qualitative tourism research. Annals of Tourism Research, 27(1), 164-187. DOI: 10.1016/S0160-7383(99)00068-7.

Salerno, F., Viviano, G., Manfredi, E. C., Caroli, P., Thakuri, S., \& Tartari, G. (2013). Multiple Carrying Capacities from a management-oriented perspective to operationalize sustainable tourism in protected areas. Journal of Environmental Management, 128(October), 116-125. DOI: 10.1016/j.jenvman.2013.04.043.

Sedmak, G., \& Mihalic, T. (2008). Authenticity in Mature Seaside Resorts. Annals of Tourism Research, 35(4), 1007-1031. DOI: 10.1016/j.annals.2008.07.004.

Self, W., \& Steadman, R. (2007). Psychogeography: Disentangling the Modern Conundrum of Psyche and Place. New York, USA: Bloomsbury.

Šípek, J. (2001). Úvod do geopsychologie: Svět a putováni po něm v kontextu současné doby (Introduction to geo-psychology: World and wandering through it in the context of the present time). Prague, Czech Republic: ISV Publishing.

Šípek, J., \& Štyrský, J. (2007). Kapitoly z geopsychologie (Chapters from geo-psychology). Hradec Králové, Czech Republic: Gaudeamus.

Šípek, J., Kacetl, J., \& Štyrský, J. (2012). Vybrané psychologicko-sociologické souvislosti cestování (Selected Psychological and Sociological Connections with Travelling). Czech Journal of Tourism, $1(1), 18-29$.

Siwek, T. (2011). Percepce geografického prostoru (Geographic Space Perception). Prague, Czech Republic: Česká geografická společnost Praha. 
Sternberg, R. J., Sternberg, K., \& Mio, J. S. (2011). Cognitive psychology. Belmont, CA/Wadsworth: Cengage Learning.

Svobodová, K. (2011). Percepce krajiny: Výzkum a využiti ve strategickém plánováni (Landscape perception: Research and use in strategic planning). Prague, Czech Republic: Czech Technical University in Prague. Retrieved from http://cvut.mapovyportal.cz/percepce_krajiny.pdf.

Thagard, P. (2005). Mind: Introduction to Cognitive Science. Cambridge, MA: MIT Press.

Tolman, E. C. (1948). Cognitive Maps in Rats and Men. The Psychological Review, 55(4), 189-208. DOI: $10.1037 / \mathrm{h} 0061626$.

Ulrich, R. S. (1983). Aesthetic and affective response to natural environment. In I. Altman \& J. F. Wohlwill (Eds.), Human behavior and environment: Advances in theory and research 6 (pp. 85-125). New York: Plenum.

UNESCO. (2015). Operational Guidelines for the Implementation of the World Heritage Convention. Paris: UNESCO World Heritage Centre. Retrieved from http://whc.unesco.org/en/guidelines/.

Walle, A. H. (1997). Quantitative versus qualitative tourism research. Annals of Tourism Research, 24(3), 524-536. DOI: 10.1016/S0160-7383(96)00055-2.

Walmsley, D. J., \& Jenkins, J. M. (1992). Tourism cognitive mapping of unfamiliar environments. Annals of Tourism Research, 19(2), 268-286. DOI: 10.1016/0160-7383(92)90081-Y.

Wilson, E., \& Hollinshead, K. (2015). Qualitative tourism research: Opportunities in the emergent soft sciences. Annals of Tourism Research, 54, 30-47. DOI: 10.1016/j.annals.2015.06.001.

Young, M. (1999). Cognitive maps of nature-based tourists. Annals of Tourism Research, 26(4), 817839. DOI: 10.1016/S0160-7383(99)00023-7.

Zelenka, J. (2009): Genius loci. In D. Krámský (Ed.), Kognitivni věda dnes a zítra (Cognitive science today and tomorrow) (pp. 207-217). Liberec, Czech Republic: Nakladatelství Bor.

Zelenka, J. et al. (2008a). Percepce krajiny a genius loci (Landscape perception and genius loci). Hradec Králové, Czech Republic: Gaudeamus.

Zelenka, J. et al. (2008b). Výzkum kognitionich a mentálnich map (Research of Cognitive and Mental Maps). Hradec Králové, Czech Republic: Gaudeamus.

Zelenka, J., \& Pásková, M. (2007). Mentální mapy - úvod do problematiky a metodika výzkumu na Univerzitě Hradec Králové (Mental Maps - Introduction to Subject and Research Methodology at the University of Hradec Králové). EE⿱乛⿻M Economics and Management, 10(1), 68-76.

Zelenka, J., Vybíral, B. et al. (2013). Kognice prostoru (Space Cognition). Hradec Králové, Czech Republic: Gaudeamus. 